\title{
Borderline microscopic organism and lockdown impacted across the borders-global shakers
}

\author{
Shariq Suleman ${ }^{1} \cdot$ Asim Farooqui ${ }^{1} \cdot$ Pradakshina Sharma $^{1} \cdot$ Nitesh Malhotra $^{2} \cdot$ Neelam Yadav $^{3,4} \cdot$ Jagriti Narang $^{1}$. \\ Md Saquib Hasnain ${ }^{5}$. $\cdot$ Amit Kumar Nayak ${ }^{6}$
}

Received: 9 August 2021 / Accepted: 16 November 2021 / Published online: 29 November 2021

(c) The Author(s), under exclusive licence to Springer-Verlag GmbH Germany, part of Springer Nature 2021

\begin{abstract}
Viruses are the potential cause of several diseases including novel corona virus-19, flu, small pox, chicken pox, acquired immunodeficiency syndrome, severe acute respiratory syndrome etc. The objectives of this review article are to summarize the reasons behind the epidemics caused by several emerging viruses and bacteria, how to control the infection and preventive strategies. We have explained the causes of epidemics along with their preventive measures, the impact of lockdown on the health of people and the economy of a country. Several reports have revealed the transmission of infection during epidemic from the contact of an infected person to the public that can be prevented by implementing the lockdown by the government of a country. Though lockdown has been considered as one of the significant parameters to control the diseases, however, it has some negative consequences on the health of people as they can be more prone to other ailments like obesity, diabetes, cardiac problems etc. and drastic decline in the economy of a country. Therefore, the transmission of diseases can be prevented by warning the people about the severity of diseases, avoiding their public transportation, keeping themselves isolated, strictly following the guidelines of lockdown and encouraging regular exercise.
\end{abstract}

Keywords Viruses $\cdot$ Bacteria $\cdot$ Epidemics $\cdot$ Lockdown $\cdot$ Infectious diseases $\cdot$ Transmission $\cdot$ Vector

\section{Introduction}

Borderline organisms or viruses are the organisms that easily qualify all the features needed to be including in epidemics or pandemics. When any diseases caused by such microorganisms are tuned into epidemics, it becomes very difficult to control the rate of infection. Infectious diseases caused by viruses are highly dangerous and occur due to their multiplication inside the human body (Hollmann et al. 2021). These are ultramicroscopic entities that are inactive in the outside environment. However, they get attached to the host cell surface and inject their genome to replicate themselves using host enzymes. Viruses are severe infectious diseases causing agents which can transform into pandemics (World Health Organization 2020). The diseases caused by viruses are communicable. The prevention of viral infection is very complicated due to the lack of proper diagnostics and therapeutics. As a result, viral diseases take a shape into epidemics. Worldwide, a large number of viral, bacterial and fungal epidemics have been reported (Bongomin et al. 2017). These viral pandemics involve a response from thousands of healthcare workers (HCWs) globally (Brooks 
et al. 2018). Therefore, providing frontline healthcare during viral pandemics has increased several threats such as long-term or short psychological imbalance, anxiety, depression, anger, and fear to HCWs (Serrano-Ripoll et al. 2020; Maunder et al. 2006). Recently, in December 2019, a virus pandemic was reported by World Health Organization on 11th March 2020 due to infection caused by novel corona virus 19 (COVID-19). This COVID-19 pandemic has greatly increased the mortality of people worldwide. Moreover, consequences of these epidemics include reduced people immunity so that they are more vulnerable to other diseases, a high death rate, and interruption of the healthy life cycle of human beings and most significant is a decline in the economy of a country (Bloom and Cadarette 2019a, b). This is due to the non-availability of adequate vaccine or therapeutic components because of the generation of a new strain of infecting agent or resistant strain (Roy 2020). Therefore, in such circumstances of a pandemic, it is essential for a country to suspend all the on-going activities like public transport including airports, schools, and colleges and prevent huge gatherings in public places to maintain the social distancing among the people (Paital et al. 2020; Modesti et al. 2020) since lockdown was seen as a prevention step to reduce the spread of primary infection among the population (Atalan, 2020). Lockdown is an emergency protocol to prevent the movement of people from one place to another (Grover et al. 2020). Strict lockdown protocol renders persons to stay where they are not allowed for entry and exit movements. This is both a powerful method for preventing the spread. Cross-border cooperation should be actively pursued and supported at all levels of government, to promote a coherent response approach across a broad territory (e.g. border closure and reopening, containment measures, exit strategies, migrant workers) and an emergency strategy for saving lives of susceptible or at-risk individuals. Therefore, in such a situation, government of any country can completely close educational institutions, shopping arcades, factories, offices, local markets, transport vehicles, airports, railways, metros, and buses except hospitals, police stations, emergency services such as fire stations, transport fuels and foodstuffs. But it happens only when the people follow the rules and regulations of lockdown properly however if it is not a success due to premature withdrawal then the infection rate hikes in the communities. Consequently, people die enormously. Recently, Grover et al. (2020) reported the importance of social distancing to improve the health of people by controlling the spread of infection caused by novel corona virus 19 in various countries including China, the USA, Italy, France, and Malaysia. During pandemics, the old age group people, new born, pregnant women and people who have already been the victim of some other diseases such as asthma, diabetes, high blood pressure people have been found more susceptible to pandemics (Mishra et al. 2020; Tabish et al.
2020; WHO 2019). However, the after-effects of pandemics and epidemics worsen political pressures and conflicts in countries with poor institutions and a history of political turmoil. Quarantines and other outbreak response strategies have caused violence and hostility between states and civilians in these situations (Madhav et al. 2017). Epidemics and pandemics can cause severe morbidity, i.e. immunocompromised individuals and mortality, as well as societal, political, and economic instability. Providing high-quality treatment before and during these situations is a top priority for public health, posing many logistical, bureaucratic, and therapeutic challenges. Hence, there is a big challenge for the researchers to answer all the serious challenges of distinct epidemics. Moreover, the scientific communities in the field of medical, they can mitigate the hazardous effects of epidemics by designing some effective diagnostics and therapeutics like vaccines and antibiotic drugs. Recently, the world is severely affected by the loss caused by COVID-19 epidemics (Mishra et al. 2020; Tabish et al. 2020). Therefore, in this review article, we have discussed the cause of epidemics, almost all the viral and their best possible preventive measures. This review article also emphasizes the impact of lockdown on the human health and economy of a country.

\section{Cause of epidemic or pandemic}

Several factors have been found significant for a virus pandemic. So, herein we discussed a list of parameters for virus pandemic:

i) Public transmission and behaviour

Earth has a huge population; therefore, if any infectious agent like virus encounters that allows more risk of virus transmission from one person to another. Furthermore, the movement of people from one place to another is also quite more which drastically transmit the virus to distantly located people at a faster rate. In the 2014-15 pandemic, the infectious disease was spread due to cultural customs or social gatherings. For instance, people in West Africa who cared for sick families were got infected with the Ebola virus due to interaction with contaminated body fluids. Consequently, they facilitated the transmission of the virus from infectious families to other people (Jacob et al. 2020).

ii) Variations in vector reservoir populations

The virus changes its vector for the transmission of diseases and thereby virus reaches to new environment and communities as well. This consequence was found critical in the transmission of the West Nile virus. It was observed that this virus spread in Western Hemisphere through an infected person or mosquitoes found in Eurasia. Once the virus grows in the confined population of urban New York town, from where it reaches the new atmosphere and showed its effect on different birds and mosquito species. Consequently, the 
virus population was increased and that facilitated more viral transmission in the entire USA (Randolph and Rogers 2010).

iii) Effect of altered weather and climatic conditions

Weather and climate alteration are also important parameters for a virus to cause a pandemic. Because alteration in weather as well as climatic conditions facilitates the movement of animals bearing virus to distinct locations and therefore, spread the infection to new communities. The effect of weather and climate on virus epidemic was observed in an outbreak caused by Hantavirus in 1993 although the change in weather and climate from the normal generally affects the growth of pathogens it sometimes provides the optimum state for growth when the climate returns to its normal conditions it also declines the movement of pathogens due to the lack of optimum condition. During this outbreak due to heavy rainfall, a large number of the plant grew which in turn increased the number of rodents. After sometime, the new habitats of rodents were extinct due to normal weather and climatic conditions. As a result, rodents for their food and habitat moved to homes and infected local communities with Hantavirus. The pandemic was ended by building rodent-proof homes in that area. Moreover, Aleya et al. (2021) reported that SARS-CoV infection is transmitted by air pollution caused by anthropogenic activities. Environmental humidity increases the incidence of viral infection. The impact of global warming on Vibrio cholera has also been revealed (El-Sayed and Kamel 2020). This is due to high temperature enhances the growth of zooplanktons in the water bodies. Consequently, V. cholera develops a symbiotic relationship with the planktons; therefore, swimmers with open wounds get a bacterial infection.

iv) Mutations in the genome of infecting agent

A virus becomes pandemic when it changes its genetic material due to mutations. For example, the spread of the influenza virus in the population was due to mutations caused in the viral genome by genetic drift. Mutations in the flu viral genome are the significant cause of the influenza epidemic. Therefore, it was very difficult for the researchers and pharmaceutical companies for developing vaccines for the flu virus (Webster and Walker, 2003). Primary transmission and infection caused by several zoonotic diseases have been depicted in Fig. 1.

An epidemic is the drastic spread of diseases consequently at the same time a disease is transmitted to the entire population. The epidemic happens when the number of cases of illness is unexpectedly increasing. An epidemic may arise
Fig. 1 Various zoonotic diseases showing their mode of primary transmission and infection
- Pneumonic-Human to Human via droplets

- Bubonic- From flea bites or direct contamination from infected rodents

\section{- Primarily from wild bats, civets then human to human transmission through aerosol} By Faecally
contaminated
water and food
Contact with dromedary
camel and camel products
- Primarily through infected animals (Gorilla, monkey, chimpanzee porcupine, antelope) further human to human contact through with contact.
Primarily by bite of Aedes mosquitoes, Through sexual contact, blood transfusion and organ transplantation

- Animal such as avian, swine and infected humans Primarily than human to human transmission 
in a population, geographic region or several countries. It is a condition to demonstrate any out-of-control crisis. Examples of several epidemics are the Spanish flu epidemic in 1918, the measles epidemic reported in 1981-1991, and whopping cough an outbreak is a pandemic reported in 2014 as it occurs through large regional regions and impacts a significant portion of the population. In brief, a pandemic can be defined as an epidemic that is on a regional or global level. Furthermore, past pandemics such as pandemics due to HIV/AIDS documented in1968, COVID-19 pandemic in 2020, SARS-CoV in 2003, MERS-CoV in 2012, Ebola virus in 1976, influenza pandemic in 1918, 1957 and 1968, ZIKA virus pandemic in 2007 and 2015 and 3 plague pandemics first reported in 6th-8th centuries, second 14th-19th century (Black death) and third at the beginning of 19th century and cholera pandemic in 1816. Declaration of pandemics of any diseases by a country allows national and global public health authorities to adapt preventive measures globally to the crisis. (Brower and Chalk 2003). Figure 2 depicts the timeline of various epidemics from past to recent periods with the number of deaths reported. Education programs will be introduced to encourage traveller safeguards, washing of hands regularly, coughing identification and the usage of personal safety equipment (such as masks) while entering public places. This extraordinary accomplishment was only possible in the absence of vaccines and antivirals, leading to the robust application of conventional public health interventions. These public health initiatives aim mainly to avoid the spread of disease by creating distance among people that disrupt the transmission of the virus. The widest approaches include isolation and quarantine, public detachment and containment of the population. Isolation provides a segregation zone for patients suffering from infectious diseases to non-infected individuals to cover uninfected individuals. 'Quarantine' is among the oldest and most potent methods to manage highly infectious disease outbreaks. Quarantine involves the restriction of travel by people that are infected with a disease but not showing symptoms of illness that may be either due to they are not infected or still in the incubation phase (Cetron and Landwirth 2005). 'Social distancing' is
Fig. 2 Timeline showing various pandemic/epidemics outbreak from history to modern period with the no. of deaths reported

\section{Pandemic/Epidemic from history}

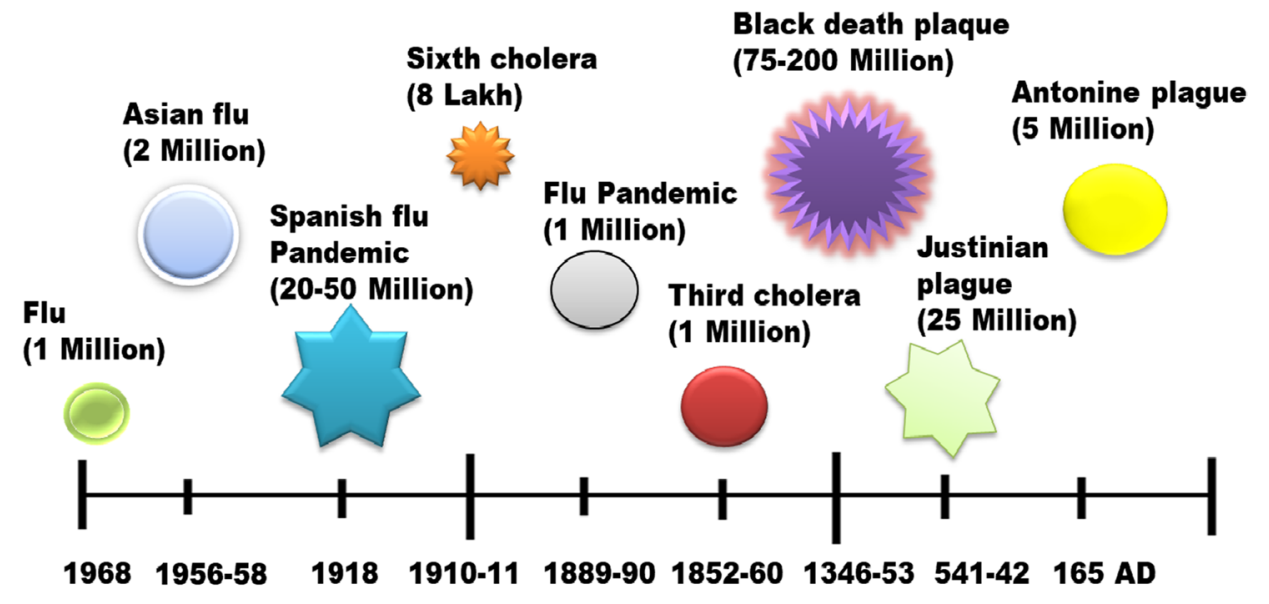

Modern Pandemic / Epidemic

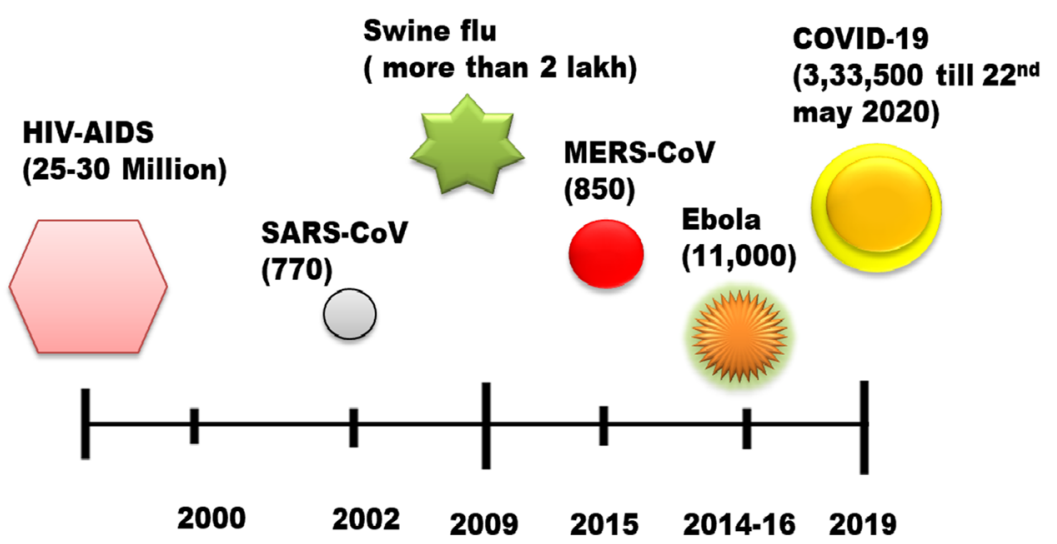


intended to minimize connections with people in a larger society, in which people may be contagious but have not yet been identified. Herein, this reviews various epidemics or pandemics and preventive measures taken to combat the risk are discussed. The review also describes that the epidemic resulted in lockdown conditions and how they impacted the overall health and economic conditions.

\section{Journey of various epidemics}

Infectious diseases can result from several distinct types of microorganisms including bacteria, fungi, parasites and viruses (Halstead et al. 2010). Among these, infectious diseases caused by viruses are fatal if they are not diagnosed and treated timely. Viruses are ultramicroscopic germs which are having DNA or RNA as genetic material and are covered by a layer of protein. The envelope of some viruses is also covered by a layer of fat. They cannot multiply themselves. Therefore, they rely on host enzymatic machinery for their multiplication (Fenner et al. 2013). There are different types of viruses that are responsible for causing different infectious diseases viz. chickenpox, smallpox, influenza, herpes, acquired immune deficiency virus, viral hepatitis, meningitis, pneumonia, gastroenteritis, shingles, mumps, measles, rubella and many more (Mehendale et al. 2013). Besides these, several other infectious diseases causing viruses include Marburg virus, Ebola virus, Rabies, Hantavirus, Dengue, Rotavirus, SARS-CoV (severe acute respiratory syndrome), SARS-CoV2 (coronavirus) and Middle East Respiratory Syndrome (MERS-CoV) (Meganck and Baric 2021). In addition to these aforesaid viruses, several other viruses have been categorized into types of infectious diseases caused by them. Table 1 depicts the different types of viruses which are responsible for distinct infectious diseases https://www.onhealth.com/content/1/viral_infections.

Therefore, herein we have explained the various viral and bacterial epidemics with their preventive measures:

\section{COVID-19 epidemic}

COVID-19 is a modern virus-causing infectious disease whose outbreak first occurred in Wuhan, China. It has flu-like signs of cough, nausea and even respiratory problems. By 16th March 2020, the rate of COVID-19 patients reported outside China had increased exponentially and the number of nations, including not only states but also territories, affected that reported infections to WHO was 143 (Wu and McGoogan 2020). Coronavirus disease 2019 (COVID-19) has also been detected and is spreading quickly in Europe, North America, Asia and the Middle East, with the first confirmed cases found in African and Latin American nations. On March 11th 2020, Director-General of WHO described the COVID-19 condition as a pandemic on the

Table 1 Different types of viruses and related infectious diseases

\begin{tabular}{|c|c|c|c|}
\hline Sr. no. & Type of viruses & Name of viruses & Diseases caused \\
\hline \multirow[t]{2}{*}{1.} & \multirow[t]{2}{*}{ Respiratory viral infections } & Rhinovirus & $\begin{array}{l}\text { Common cold } \\
\text { Seasonal influenza }\end{array}$ \\
\hline & & Respiratory syncytial virus (RSV) & Pneumonia and bronchitis \\
\hline 2. & Viral skin infection & $\begin{array}{l}\text { Herpes simplex virus } \\
\text { Varicella zoster }\end{array}$ & $\begin{array}{l}\text { Cold sores } \\
\text { Chickenpox }\end{array}$ \\
\hline 3. & Food borne virus & $\begin{array}{l}\text { Hepatitis A } \\
\text { Norovirus } \\
\text { Rotavirus }\end{array}$ & $\begin{array}{l}\text { Yellow skin, nausea, diarrhea } \\
\text { Gastrointestinal illness } \\
\text { Severe watery diarrhea }\end{array}$ \\
\hline 4. & Sexually transmitted viral infection & $\begin{array}{l}\text { Human papilloma virus } \\
\text { Hepatitis B } \\
\text { Herpes simplex virus }-2 \\
\text { Human immunodeficiency virus (HIV) }\end{array}$ & $\begin{array}{l}\text { Genital wart (cervical cancer) } \\
\text { Inflammation in liver } \\
\text { Genital herpes } \\
\text { Acquired immunodeficiency syndrome (AIDS) }\end{array}$ \\
\hline 5. & Other viral infection & Epstein barr virus (EBV) & $\begin{array}{l}\text { Fever, fatigue, swollen lymph nodes, enlarged spleen } \\
\text { (Mononucleosis) }\end{array}$ \\
\hline & & West nile virus & Encephalitis, meningitis \\
\hline 6. & Viral cancers & $\begin{array}{l}\text { Epstein barr virus (EBV) } \\
\text { Hepatitis B and Hepatitis C } \\
\text { Human immunodeficiency virus (HIV) } \\
\text { Human T-lymphotropic virus (HTLV-1) } \\
\text { Human papilloma virus (HSV) } \\
\text { Merkel cell polymavirus }\end{array}$ & $\begin{array}{l}\text { Burkitt lymphoma, hodgkin's lymphoma, stomach cancer } \\
\text { Liver cancer } \\
\text { Kaposis sarcoma, invasive cervical cancer, lymphomas } \\
\text { T-cell leukemia } \\
\text { Cervical cancer } \\
\text { Skin cancer }\end{array}$ \\
\hline
\end{tabular}


grounds of "disturbing levels of distribution and intensity of infection" (Zhou et al. 2020). Like other new high-threat diseases, COVID-19 in China and many other nations also infected health care personnel. Epidemiological reports in China indicate that approximately $85 \%$ of diseases transmission occurs from man-to-man in family clusters and infected doctors and nurses with the lack of significant nosocomial outbreaks and any convincing proof of illness in their communities by some healthcare staff (Huang et al. 2020; Wang et al. 2020). Hence, the above said apprehensions indicate that near and insecure contact is the cause for the transmission of disease in the nearby surrounding of those with infection through direct contact or interaction with contaminated materials. Continuing accounts from outside China say the similar dissemination to similar connections and individuals attending the same social activities or in different places such as workplaces or cruise ships (Ahnert et al. 2019; Snijders et al. 2012). It primarily causes respiratory infection in cows, pigs and birds (El-Sayed and Kamel 2021). Prevalence of hazardous effects of COVID-19 is mainly due to its high infectivity, use of diverse receptors by the CoV for invading the host tissues, quick and well adaptation of virus in the host system, excretion of $\mathrm{CoV}$ entities through urine, milk and nasal droplets and its persistence at high temperature (El-Sayed et al. 2021a, b). Presently, infected persons are being diagnosed by PCR and other serological tests by recognizing virus-specific antibodies (Bedford et al. 2020).

\section{Preventive measures of COVID-19}

WHO recommended the use of PPE containing N95 respiratory mask, gloves, gown, face shield and goggles for the frontline healthcare workers (Hossnain et al. 2020). Furthermore, gloves fabricated with nitrile and latex have been more preferred during the COVID-19 pandemic. An insulation space, which can be fitted with negative pressure for reducing the spread of infection via aerosols, but control, has been achieved without negative pressure chambers for large droplets like SARS-CoV. Patient isolation is especially successful when communication is disrupted if early identification before overtviral shedding is feasible (Nishiura et al. 2012). The quarantine can be optional, or mandatory, both persons should be checked for any symptoms when in quarantine. When such signs arise, patients must be treated promptly in a specified area associated with the diagnosis of acute respiratory illness. Since respiratory droplet-borne diseases require some proximity to individuals, therefore by maintaining social distance among persons can reduce the rate of infection transmission. Because social distancing has been found effective in situations where the movement of people from a community is possibly taking place but where the relations among infected patients are uncertain and constraints imposed solely on individuals known to have been exposed are inadequate for preventing recurrent infection spread (Gostic et al. 2020). Examples of social isolation involve shutting classrooms or offices and halting community services to avoid meetings.

\section{SARS-CoV epidemic}

The province of Guangdong is the site of the massive 2003 SARS epidemic, which has infected about 8000 people and 774 lives have been lost (He and and 52 others 2004). The emergence, dissemination and perseverance of diseases are encouraged due to the movement of contemporary people. The SARS outbreak caused a great deal of misery, substantial mortality, considerable disturbance of social and labour practices and major economic losses. In certain nations, draconian public safety policies including hundreds or thousands of residents being segregated and quarantined and stringent travel limits had to be placed in some countries. Chinese consultants have adopted the intervention after the recurrence of SARS infection at end of 2003 was due to the discard of the colonies of civet cat on the animal markets and breeding farms, reported to have included the evacuation of over 10,000 animals (Watts 2004). Human beings are very similar to the strain observed in civet animals but somewhat distinct to the strain affected in 2003. Better scrutiny of animals in environments where the human infecting virus travels widely to recognize the sources of the disease in men and the function of animal reservoirs is a high priority. Widespread epidemics of new infection-causing pathogens are expected to escalate in the 21 st century relative to the previous era in human history. It is also important to plan and the 'SARS' epidemic offered several apprehensions for coming years. The SARS outbreak explicitly demonstrated how successful international cooperation (and competition) contributed to the early release of the complete genome sequence of the SARS-CoV (Anderson et al. 2004).

\section{Preventive measures of SARS-CoV}

Preventing SARS relies on the rapid detection of cases and the early adoption of protection measures including isolation of patients, the usage of suitable personal protection gear, contact control and possibly quarantine. Effective identification and treatment of SARS patients are critical in reducing the spread of infection. Infection prevention strategies for alleged SARS include the following, based on knowledge of disease transmission.

Despite the lack of appropriate antiviral treatment and vaccines, infection prevention steps remain the most relevant tool for stopping the spread of SARS from human to human. It is necessary to isolate the suspected patients early to avoid nosocomial transmission (Chowell et al. 2003). Screening and triage, the $\mathrm{CDC}$ proposed that patients be screened with 
specific questions in hospital facilities as soon as possible upon admission or on the line for an appointment. Easy screening device was used for the screening of all patients. The infected person confirmed on first screening should use a mask to isolate from other infected persons, keep them in the test room. Such infected patients should be screened again with an airborne N-95 respirator and doctors must use gowns and gloves when they handle the patients. When during this evaluation the patient matches the CDC case report for SARS and needs treatment, the patient may be admitted to a negative air room. If treatment is inappropriate or further tests are required, the patient should be accompanied to suitable areas (for laboratory investigation, radiological samples, etc.) and extended testing to avoid interference with other patients (Sampathkumar et al. 2003).

\section{MERS-CoV epidemic}

MERS-CoV was first isolated and identified in Jeddah, KSA, in June 2012 in a 68-year-old man and died due to pneumonia and multi-organ failure (Zaki et al. 2012). This was the second most severe infection after coronavirus severe acute respiratory syndrome, SARS-CoV. Coronavirus was identified as a lethal zoonotic human pathogen of the $21 \mathrm{st}$ century. The observation from serological tests has indicated that camels had MERS-CoV infection for 20 years. MERS-CoV has infected the camels and it has been documented that there are very few chances of human infections caused by camel zoonotic infection (Reusken et al. 2016). Intermittent cases have been found in the MERS-CoV cases (Memish et al. 2014) and hospital outbreaks (Assiri et al. 2013). MERS-CoV hospital case clusters represent the primary location where MERS-CoV has been rapidly transmitted human-to-human (Memish et al. 2013). The infection caused by SARS-CoV has been spread primarily by nosocomial transmission, but MERS-CoV's transmission characteristics are less evident (WHO 2013). Although KSA accounted for $90 \%$ of recorded MERS-CoV cases, MERS-CoV was infected in around 27 countries including Europe, North Africa, Asia, the (U.S) United States and the Middle East. MERS-CoV remains the priority on "emerging pathogens that are likely to cause big epidemics" in the WHO list (WHO 2016). However, several questions remain unanswered about MERS-CoV epidemiology, pathogenesis, management, and control (Zumla et al. 2016).

\section{Preventive measures of MERS-CoV}

Understanding of MERS-CoV zoonotic causes helps in the prevention of disease. According to guidelines of WHO, people with MERS-CoV infection include measures such as restrain from touching and coming in contact with either camels or their products, hygiene all surface touching body parts and restricted or no use of raw milk, washed, cleaned the food items and cooked them properly (WHO 2014). Because mostly infections caused by any pathogen occur in the contaminated environment. Therefore, it is recommended that doctors and nurses should take adequate steps to prevent infection during the monitoring of patients with MERS-CoV (WHO 2015). There is currently no clear treatment or vaccine available for treating MERS-CoV infection. Yet, there are currently a variety of antiviral drugs under review (Zumla et al. 2015). No vaccine is recommended for avoiding infection caused by MERS$\mathrm{CoV}$. However, to avoid the transmission of contagion, an experimental MERS-CoV vaccine has been designed by a pharmaceutical company (Novavax 2013). The company has also developed several aspirant vaccines that are being tested as a full-length MERS-CoV infectious viral genome cloned in a bacterial artificial chromosome. There are currently no appropriate drug treatments for treating or avoiding the infection. Clinically, patients with a serious disease can be cured by meticulous intensive care and complication avoidance like hydration, antipyretics, analgesics, respiratory assistance and, if applicable, antibiotics for superb bacterial infection. The new protocol depends on earlier practices for severe acute respiratory syndromeCoronavirus (SARS-CoV), in vitro trials, and case series. Diverse therapeutic components were tested, that block the invading of viruses and their replication inside the host system (Al-Tawfiq and Memish 2014).

\section{Ebola virus epidemic}

Ebola virus disease was firstly reported in 1976 and recorded a high death rate due to haemorrhagic fever in two parallel outbreaks. The first outbreak was reported in Nzara, (Sudan) and the other in Yambuku, Democratic Republic of Congo (formerly Zaire), Central Africa (WHO 2015). Many Ebola outbreaks have affected approximately 1-400 patients and the prevalence was mainly seen in remote forest areas (WHO 2015). The Zaire strain of Ebola was originated in a small village in Guinea, West Africa in December 2013; however, Ebola diseases were not identified until March 2014. This transmitted quickly causing Africa's worst and elongated Ebola epidemic (WHO 2015). A total of 24,666 cases of Ebola were confirmed in Guinea, Liberia and Sierra Leone as of 18 March 2015, including 10,179 deaths. Countries including Nigeria, Mali, Spain, Senegal, the UK and the United States (U.S) were registered for importing cases from the countries affected in West Africa. Man-to-man spread of Ebola comes from symptomatic patients due to interaction with the affected body fluids. For the disease, the normal incubation time is 8 to 10 days (Suwantarat and Apisarnthanarak 2015). 


\section{Preventive measures of Ebola}

Prevention is focused on preventing viral contact. The following measures will help prevent Ebola from forming and spreading. Ebola may be fatal; anyone in direct contact with an infected individual's body fluids is at increased risk of spreading the infection oneself. Wash the hands properly, safely mount and uninstall personal protection equipment and other precautions are necessary. Since Ebola can spread across borders, the appropriate infection prevention and control steps must be planned for all countries. Frequent hand-washing is one of the most effective prevention steps. Using soap and water or using drug-based hand pieces that contain 70\% drug where there is no soap and water available (Bray et al. 2015). Avoid contact with a sick person. Carers should prevent direct contact with the fluids of the infected individuals and tissues of disease-carrying persons, including blood, semen, vaginal secretions and saliva. During later stages of the disease, those with Ebola or Marburg are more infectious. Employ protocols to manage infections. When you are a health official, wear appropriate gear including boots, helmets, gowns and eye covers. Hold the persons infected isolated from others. Disposing of needles and sterilizing others. The remains of those who suffer from Ebola or Marburg fever appear to be infectious. Reducing the risk of animal infection to humans by preventing the contact with infected fruit bats or monkeys/apes and avoiding the ingestion of raw meat. Outbreak prevention steps, including timely and secure burial of the deceased, the detection and surveillance of individuals who may have been in touch with someone diagnosed with Ebola for 21 days, the importance of distinguishing the well from the ill to avoid further spread and the importance of good grooming and a clean atmosphere (Bray and Geisbert 2005).

\section{Influenza epidemic}

Influenza has remained the major cause of morbidity and mortality, instead of the availability of vaccines in recent years (Cox and Subbarao 2000). The human population has not shown immunity to the emerging new strain of influenza virus as a result converted into pandemics worldwide. It has been reported that in the pandemic of 1918 due to A / H1N1 had lost 20-50 million lives globally (Johnson and Mueller 2002), whereas the pandemics of other influenza virus strains including A / H2N2 and A / H3N2 were reported in 1957 and 1968 respectively. These pandemics were less severe in the $1918 \mathrm{~A} / \mathrm{H} 1 \mathrm{~N} 1$ pandemic and about one million people were died (Nguyen-Van-Tam and Hampson 2003). These epidemics mostly occur in the winter season due to continuous viral antigens modification by host loss the immunity (Plotkin et al. 2002). The effect of these annual epidemics on mortality differs considerably with years
(Simonsen et al. 2005). Moreover, the extent of severity relies on the prevalent subtype of the influenza virus. It has been reported that $\mathrm{a} / \mathrm{H} 3 \mathrm{~N} 2$ influenza strain is more virulent than others (Simonsen et al. 1997). However, it is interesting that there are significant residual variations in the effect of infectious mortality and morbidity within a given subtype. In the US, for example, there has been a four-fold gap in the effect of mortality between the moderate and extreme A / H3N2 seasons. It was shown that the influenza outbreak of 1951 had an extraordinarily high effect on mortality in England and Wales. The mortality rate was more in 1951 than the pandemics of 1957 and 1968, and a greater mortality effect than all three Liverpool pandemics. Another peculiar characteristic of the 1951 outbreak was the study of multiple mortality and morbidity disease curves. The laboratory data gathered during the 1951 outbreak by the WHO monitoring network provide information as to what the exceptionally serious influenza strain of 1951 had been. Influenza viruses that spread in England, Wales and Canada during the winter of 1951 were identified as A / H1N1, and Hemagglutinin-inhibition study performed did not display significant variations in the Hemagglutinin antigen (Isaacs et al. 1952). This epidemiological and virological data has indicated a virus without totally new antigens (i.e. no shift) (Viboud et al. 2006).

\section{Preventive measures of influenza}

Numerous interventions have proved their efficacy in influenza prevention. Nevertheless, the community was not well aware of the position of various risk exposures and preventive measures against influenza. The key prevention method is influenza vaccines, but the safety benefit obtained is not always attained either because the vaccine does not suit up with the circulating viral strain, or because a new pandemic virus appears (Nichol et al. 2007). Some findings from the intervention have shown that alcohol-dependent hand-washing or hand sanitisers can reduce the risk of influenza (Bell and World Health Organization Writing Group 2006). The public is concerned with measures to avoid non-pharmacological influenza and stresses common precautions such as cover the mouth while coughing or sneezing and washing hands gently.

\section{ZIKA virus epidemic}

ZIKA infection was spread due to the sucking of blood by diurnal-active Aedes mosquitoes like Aedesaegyptiand A. albopictus (Malone et al. 2016). In Yap Island, 2007, the very first epidemic of ZIKA infection was reported and after that, it was documented in Brazil, 2015. The common symptoms of ZIKA infection include mild fever, knee pain, skin rashes, conjunctivitis (red eyes) and myalgia. It has been 
observed that most individuals diagnosed with Zika did not get sick; on the other hand people, sick individuals showed a variety of symptoms, close to dengue fever symptoms and the mortality rate was very less. Therefore, prevention and management methods are poorly applied in the patient population; however, new infections need to be avoided. Now, the ZIKA virus (ZIKA) is a worldwide epidemic. Evidence of ZIKA transmission was recorded in more than 72 countries and territories since 2007. ZIKA's spread has made the World Health Organization recognize the condition as a health emergency. This condition is bad as there appears to be an extremely visible correlation between pregnancy infection and the onset of microcephalus and Guillain - Barré syndrome (Rather et al. 2017).

\section{Preventive measures of Zika virus}

Collective duty and contribution to comprehensive vector control, in particular through eliminating contaminated water and using insecticides (diethyltoluamide/ethyl butylacetylaminopropionate)/larvicides, is strongly focused because the shortage of vaccinations and antiviral therapy against ZIKV (Lazear and Diamond 2016). A. Aegypti and A. Albopictus are the chief vectors for causing the current ZIKV epidemic, the vector management techniques and the vector-pathogen relationship of all potential mosquito species are suggested regardless of the capacity of ZIKV to evolve (Ayres 2016). It has also been advised to wear full sleeved shirts and lengthy skirts, also possibly impregnated with insecticides, to avoid interaction with the vector (Basarab et al. 2016). Barrier contraception for 28 days is recommended for asymptomatic travellers returning from endemic ZIKV regions (Wong et al. 2016). Now, public health agencies in vulnerable areas of ZIKV are advised to have access to condoms, reproductive treatment, and secure abortion facilities. Besides emphasis on preventive strategies, efforts should also be in the direction to educate the communities mainly areas with ZIKV endemic and also aware the people travelling the possible transportations of ZIKV spread (Lazear and Diamond 2016). Normal health care steps must remove the mosquitoes from health care services so that spread of autochthonous ZIKV can be prevented (Wong et al. 2016).

\section{Bacterial epidemics}

Besides viruses, bacteria have also caused severe infected diseases and sometimes results in epidemics. Bacteria are microscopic entities found in water, land and atmosphere. Some of the bacteria reside on the skin, genital organs and gut of human beings. Not all bacteria cause diseases some of them are beneficial to health such bacteria are known as good bacteria. However, certain bacteria cause highly threatened diseases including Neiserriameningitids, Staphylococcus aureus, Salmonella, Helicobacter pylori and many more. Therefore, in the given section below, we discussed the epidemics caused by plague and cholera:

\section{Plague epidemic}

Bacterium Yersinia pestis was the causal organism of endemic and it was widely researched because of its present and historical significance. According to a past report, the disease triggered a minimum of three pandemics in the present time: the principal pandemic was recorded in the 6th to 8th centuries from the Justinian Disease, the subsequent pandemic was revealed in 14th to 19th centuries from the "Black Death", and the 3rd pandemic was documented in the beginning of 19th century (Bramanti et al. 2016). Currently, a plague has been revealed in rodent lakes of several countries including Asia, Africa and the Americas. People of these countries have shown persistent danger to adjacent human residents. Bubonic and pneumonic forms of plague infection are the most prevalent (Dennis et al. 1999). When bacteria penetrate the skin, bubonic plague normally emerges from the infested flea vector. Through the bite of the vector, the bacteria transmitted to the lymph nodes and causes swelling. It has been reported that this bubonic plague transmitted from wild rodents to humans (Kugeler et al. 2015). But man ectoparasites including fleas or lice are also thought to induce transmission between humans (Drancourt et al. 2006). Respiratory plague occurs by the penetration of aerosolized bacteria to the lungs and makes them infected. This type of plague has also caused complications of bubonic/septicemic infections which is known as secondary pneumonic plague. Therefore, pneumonic plague can spread infection through the respiratory tract, but pneumonic plague outbreaks are usually limited since infected people die rapidly without care (Gani and Leach 2004). Septicemia type plague happens as bacteria enter the bloodstream, often from a $1^{0}$ pneumonic or bubonic-infection.

\section{Preventive measures of plague}

Enzootic plague has been reported in Africa, South America, and Asia. In these countries, the threat of plague in semiarid grasslands or mountainous areas is more. The risk of spreading plague from wild rodents to the village or urban centres is highest were higher population densities in plague prone rodents and poor daily sanitary activities. Persons living in plague-enzootic regions should escape rodent-infested regions. Furthermore, people working in such areas should avoid touching sick and deceased rodents. They should also use some effective repellents and insecticides for the prevention of flea biting. Travellers to plague-endemic areas are typically at low risk of infection. To minimize the risk of 
fleas being infected, travellers should protect their exposed body parts using some insect repellents and also add insecticides to outfits and outdoor duvets. In high risk of plague, the use of immediate prophylactic application of antibiotics should be avoided. It has been recommended that in anaphylaxis conditions, epinephrine hormone can be used. The efficacy and immune response generated by the vaccine has not been tested for individuals $<18$ years of age. The plague vaccine's effects on the developing foetus are still uncertain. Expecting females who are unable to escape threatened conditions must be informed of threat management strategies and will only be immunized if the possible benefits of vaccines compensate the possible threats to the growing young one. People with lower immunity or who have undergone immunosuppressive treatment may not produce antibodies after vaccination. Wherever practicable, PHA-determined antibody levels should be obtained to decide whether additional doses should be administered outside the primary series. Pest vaccination should not be given to people with a history of hypersensitivity to the vaccination or its components. Moreover, individuals suffering from an acute febrile disease like influenza cannot be immunized until they must entirely cure (Gage et al. 1996).

\section{Cholera epidemic}

Cholera is a bacterial infection that, despite continuing attempts to restrict its transmission, tends to cause outbreaks and pandemic infection. Traditionally, six cholera epidemics have ravaged the world since 1816 . The seventh epidemic was reported in Indonesia in 1961. Cholera is estimated to affect 3-5 million people in the year 2010 alone and cause $100,000-130,000$ deaths worldwide (WHO). Cholera is a small-intestinal infection caused by Vibrio cholera. The symptoms of this disease include diarrhoea and vomiting, consequently causes severe dehydration and an imbalance in electrolytes, which lead to death. As water and foodborne illness, this disease is usually associated with bacterium absorption in the form of drinking water polluted with sewage or consuming food eaten by a soiled-handed adult (ElSayed and Kamel 2020). In the meantime, various modes of transmission are necessarily possible. The cholera epidemic in a psychiatric hospital in Singapore has shown man-to-man transmission (Goh et al. 1990). Cholera poses a huge public health threat for developed countries and cholera continues to attract global consideration (Tian and Wang 2011).

\section{Preventive measures of cholera}

Cholera has been considered one of the most feared epidemics. It has raised awareness of health education campaigns and offers platforms to educate households, street vendors and caterers and implement food preparation protocols.
Furthermore, preventive steps to contain emerging epidemics include tracking the health of shellfish beds and hygienic household drinking water and food quality in the home and on the highway. Nonetheless, it is also necessary to search modes and vehicles of this disease spread (Estrada-García and Mintz 1996). There are two cholera vaccines available and recommended by two cholera vaccines approved by WHO; oral cholera vaccines are safe, successful and currently WHO licensed as follows: 1-Dukoral (Crucell, Leiden, The Netherlands) and 2-Shanchol (Shantha Biotechnics Ltd., Basheerbagh, Hyderabad, India). All vaccines are given in a double dose regimen; Vaccines are secure and allow for many years of continuous protection. Figure 3 shows the cells, tissues or organs targeted by distinct viruses and bacteria.

\section{Lockdown in various epidemics}

Lockdowns have occurred in many ways in human history, often with numerous purposes with preventing a pandemic; this has been of tremendous benefit, for example, to physicians, nurses, pharmacists and state agencies to react effectively and appropriately to the hazards of a pandemic like Covid-19. Pandemics have also been extremely volatile, due to the enormous difficulty of human-virus interactions. By using the language of safety and purity, modern rationality has accepted and regulated the establishment of borders, gated communities and quarantines that separate safe society from the unclean or unsafe. The sick person's appearance has always acted as a justification that isolates and strengthens the social and political imperatives of protecting the dignity of a "good country" against all those afflicted by the illness. The strategies can differ from changes in behaviour, such as social distance, quarantine of infectious patients, regional or national lockdown

\section{Lockdown from history}

The advent of pandemics in human history was often followed by a sequence of psychological, political and economic interventions. In 412 BC, Greek physicist Hippocrates documented an outbreak that modem physicians claim was the first influenza reference ever (Tognotti 2003). Europe eventually endured two big plague pandemics; As such, each epidemic in the West was followed by the introduction of health legislation for its confining. One of the steps taken in early modern Europe was to classify the plague victims. As early as the 15th century, several Italian city-states developed quarantines to protect those sick with the plague. In the 16th and 18th centuries, the European naval powers such as England and France introduced the custom of quarantine of those afflicted by the plague (Cohen 1974). The great 
Fig. 3 Cells/tissue/organs primarily targeted by different bacteria and virus during the onset of disease

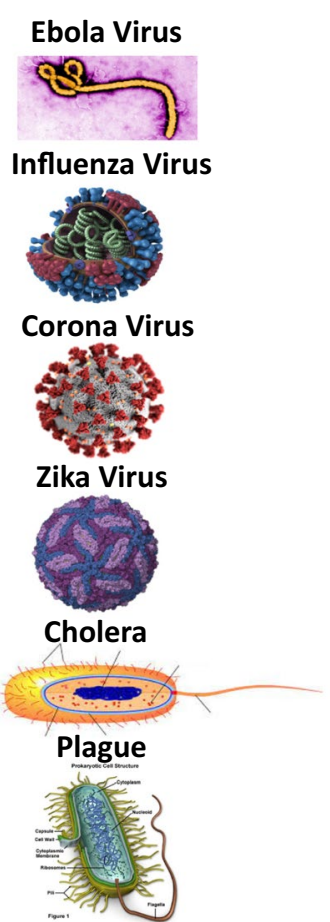

Target Cells
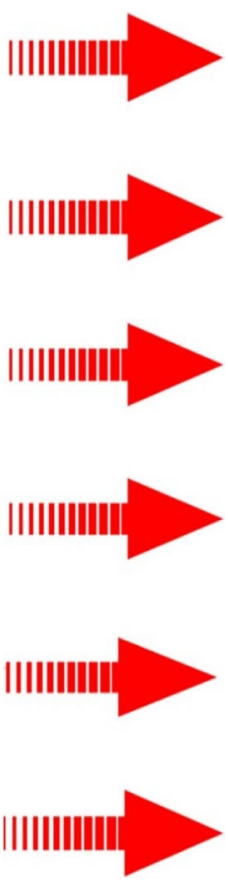

Hepatocytes, Endothelial cells, Phagocytes

Ciliated Epithelium of conducting airways

Lungs and respiratory epithelial cells

From Brain, Placenta, skin to Testis, Kidney, Retina, During Pregnancy causes microcephaly

Intestinal Epithelial Cells plague in London, 1665, and the outbreak in Marseilles, 1720, forced the French and British Governments to enact quarantine policies to prevent residents from exposure to dangerous diseases from overseas. The epidemic of 1347-48 was however attributed to Black Death patients, as part of their general mercantilist policies; the European maritime states have introduced quarantine laws, forming monopolistic trading firms. In early modern Europe, quarantine policies not only helped encourage international trade but also acted as a political mechanism for European states to substitute public health over citizens' private lives. Even in the late 18 th century, the British population became more conscious of the risks of the plague outbreak, but by the mid-19th century, the quarantine laws were relaxed (Tognotti 2013).

Europe's conclusion of the plague pandemic did not mean the planet was free of all infectious diseases. The contemporary extent and seriousness of some common diseases gave them psychological, economic and political importance that outweighed those of the two world wars of the 20th century. The 1918 influenza pandemic caused 50 million deaths worldwide (Tognotti 2013). A million people have died of influenza pandemics since 1957. Despite emerging infectious diseases such as SARS, Avian flu and Ebola having a devastating effect on the global economy and international affairs, many developing countries around the world have had to take drastic action. China's SARS epidemic in November 2002 affected over 5300 people and killed 349 people nationally. The SARS incident, however, forced the Chinese government to take punitive steps to reinforce its control by closing cities, apartment complexes and university campuses and throwing hundreds of thousands of people in prison. China's 2003 anti-SARS shutdown program accompanied by a robust disease response strategy showed China how to suppress the coronavirus outbreak by 2020 . The fact that China's proactive policies have accelerated the coronavirus does not mean that a global pandemic preventive monitoring program is becoming a reality. Pandemic control is not a straightforward job for governments and civil society around the world. Successful control will rely on many factors like identifying infected people, vaccinating the vulnerable species and decontaminating areas and items. Before now, human insulation and national lockdowns have not been replaced (Rothstein et al. 2003).

Especially for travel bans and border restrictions during the 2014-15 Ebola outbreak, projections predicting movement cuts of more than $80 \%$ projected minimal effects on the transmission of foreign diseases (Gomes et al. 2014) joining the call to measure previously unmet versatility improvements since the epidemic. Many countries and airlines have introduced travel restrictions to and from the affected region in response to these issues and to minimize the risk of case imports. Domestic travel controls remain in effect for long periods, including limits on the transport of individuals and goods and full quarantines in some areas. Schools were locked and businesses were paused, Non-Ebola healthcare programs, including maternal healthcare, deteriorated when medical facilities were asked to act when treatment centres for Ebola and patients avoided hospitals and clinics for fear 
of infection. Travel bans could impede the distribution of medical supplies and the deployment of specialist personnel to handle the epidemic (Peak et al. 2018). Among the most hit countries such as the Middle East, Africa, Europe and America, various steps have already been taken among South Korea, several schools and colleges have been closed. Most men on the road were seen sporting face masks, disinfected public transit and the attendance at movie theatres and baseball games collapsed (Qureshi and Sajjad 2018). Table 2 shows the details of almost all Pandemics/Epidemics from ancient times to the present. Redrawn from Source: LePan (2020). Visualizing the history of pandemics. Visual capitalist. com. Accessed October, 31.

\section{Impact of lockdown on health}

In the 21st century, a major coronavirus disease 2019 (COVID-19) pandemic has generated an unpredicted threat to mental health worldwide. Therefore, patients and HCWs need significant attention for their psychological boosting (Xiong et al. 2020). Xiong et al. (2020) reported COVID19 pandemic has augmented several distinct hazards viz. anxiety (6.33-50.9\%), depression (14.6-48.3\%), posttraumatic stress disorder (7-53.8\%), psychological distress (34.43-38\%) and stress (8.1-81.9\%) in different countries including China, Spain, Italy, Iran, the US, Turkey, Nepal, and Denmark. Besides respiratory illness, COVID-19 has also affected various vital organs including the lungs, heart, nerves, brain, vessels, kidneys and skin (Hossain et al. 2020). In the serious condition of $\mathrm{CoV}$, infection person leads to death due to failure of the respiratory system (ElSayed et al. 2021a, b). Moreover, this pandemic distress has increased the risk in females, youth, and the presence of chronic/psychiatric diseases, unemployment and recurrent coverage to social media/news regarding COVID-19. This pandemic has increased suspicions, fear, suicide and mental illnesses. Therefore, attention given to public psychological wellbeing and making policies to assist people through this challenging time is an urgent need of the hour.

The most successful method to minimize morbidity and mortality is possibly vaccines. Vaccines, however, are unlikely to be effective early on in a pandemic. The stock of vaccines is most likely inadequate because of the limited manufacturing capacity worldwide. The potential existence of resistant strains should be considered. Non-pharmaceutical methods (such as containment, separation and social distancing) can be successful in stopping the virus from spreading under certain circumstances. The efficacy of non-pharmaceutical treatments depends on how influenza viruses spread. The shutdown effectively shut down most modes of public and private transport, which revealed that the average amount of people-to-person communications each day among its inhabitants had decreased; ultimately, the lockout will partly stop disease spread. As of 23 January 2020, the Chinese government has shut Hubei including Wuhan, the 11 million-strong cities where the epidemic began. They prohibited to travel in and out and barred tens of millions from working or going to school and shut down all stores except those who sold food or medication. For certain areas, people were also required to restrict their visits

Table 2 Different viral pandemics illustrating their time, origin and preventive measures associated with diseases caused by viruses in the pandemics

\begin{tabular}{|c|c|c|c|c|c|}
\hline Disease & Year & City/country & Type (WHO) & Type/pre-human host & Death toll \\
\hline COVID-19 & 2019 & Wuhan (China) & Pandemic & Corona virus- Unknown & $\begin{array}{l}4,873,249 \\
\quad \text { as of } \\
12.10 .2021\end{array}$ \\
\hline SARS & 2003 & Guangdong (China) & Pandemic & Corona virus- Bats, Civets & 770 \\
\hline MERS & 2012 & Jeddah (Saudi Arabia) & Pandemic & Corona Virus- Bats, Camels & 850 \\
\hline Ebola & 2014 & Guinea (West Africa) & Epidemic & Ebola virus-Wild animals & 11,000 \\
\hline $\begin{array}{l}\text { Antonine Plague } \\
\text { Justinian plague } \\
\text { Black death } \\
\text { Third Plague }\end{array}$ & $\begin{array}{l}1320 \mathrm{BC} \\
542 \mathrm{AD}-546 \mathrm{AD} \\
1347-1351 \\
1885\end{array}$ & $\begin{array}{l}\text { Europe, North Africa } \\
\text { Asia, Africa and Europe } \\
\text { Europe and Africa } \\
\text { China and India }\end{array}$ & $\begin{array}{l}\text { Pandemic } \\
\text { Pandemic } \\
\text { Pandemic } \\
\text { Pandemic }\end{array}$ & $\begin{array}{l}\text { Believed to be either smallpox } \\
\text { or measles } \\
\text { Yersinia pestis bacteria- Rats, } \\
\text { fleas } \\
\text { Yersinia pestis bacteria- Rats, } \\
\text { fleas } \\
\text { Yersinia pestis bacteria- Rats, } \\
\text { fleas }\end{array}$ & $\begin{array}{l}5 \mathrm{M} \\
30-50 \mathrm{M} \\
200 \mathrm{M} \\
12 \mathrm{M}\end{array}$ \\
\hline Cholera & 1817-present day & Gaspar correa (Portuguese) & Pandemic & V. cholerae bacteria & $1 \mathrm{M}+$ \\
\hline $\begin{array}{l}\text { Spanish Flu } \\
\text { Asian Flu } \\
\text { Hong Kong Flu } \\
\text { Swine Flue }\end{array}$ & $\begin{array}{l}1918-1919 \\
1957-1958 \\
1968-1970 \\
2009-2010\end{array}$ & $\begin{array}{l}\text { US } \\
\text { Guizhou (Southern China) } \\
\text { Hong Kong } \\
\text { North America }\end{array}$ & $\begin{array}{l}\text { Pandemic } \\
\text { Pandemic } \\
\text { Pandemic } \\
\text { Pandemic }\end{array}$ & $\begin{array}{l}\text { H1N1 virus- Pigs } \\
\text { H2N2 virus } \\
\text { H3N2 virus } \\
\text { H1N1 virus- Pigs }\end{array}$ & $\begin{array}{l}40-50 \mathrm{M} \\
1.1 \mathrm{M} \\
1 \mathrm{M} \\
200,000\end{array}$ \\
\hline HIV/AIDS & 1981- present day & Central and west Africa & Global Epidemic & Virus- Chimpanzees & $25-35 \mathrm{M}$ \\
\hline
\end{tabular}


to the supermarket or order distribution supplies. This global shutdown of tens of millions of people has been called a "vast challenge" - but it may have succeeded. Following the lockdown, cases began to slow. On 19 March 2020, the National Health Commission of China announced no new confirmed COVID-19 infections. Nonetheless, we're already seeing a "flattening of the curve" in areas of Italy where lockdowns began earlier (Khan et al. 2020).

Quarantine was first introduced in Italy during 14th-century plague epidemics. Many scholars claim that their origins can be traced to the Hippocratic philosophy or the Old Testament; others say that Renaissance commentators interpreted the 40 days as marking the time between the death or regeneration of the plague sufferers without spreading the disease (Markel 1997). Strict maritime quarantine (in some cases with land quarantine facilities) tended to effectively prohibit the entrance into American Samoa of the 1918-19 influenza pandemic and postponed its penetration into mainland Australia, Tasmania and New Caledonia (Markel 1997). A systematic analysis has found that measures including quarantine (2 studies) and isolation (10 studies) have been successful in the prevention of respiratory virus epidemics (Jefferson et al. 2008). An analysis shows that quarantine strategies are more successful if implemented at the very beginning of the epidemic where there are small numbers. Quarantine-related analyses from actual SARS outbreaks usually show an infection curve of case counts against the sequence of incidents including the frequency of index cases and improvements in the response to public health. The effect of the prevention steps is indicated by contextual findings, such as the noticeable deceleration of new cases in plots or the subsequent conclusion of the outbreak (Svoboda et al. 2004; SARS 2005). Many of these studies emerged long after the epidemic, with attempts to complete details on the beginning dates and retrospectively transmission. The use of public quarantine during the 2003 SARS epidemic in Ontario limited spread to one third. According to a study, it was proposed that a decrease in the number of near contacts led to a decline in range, and this may have ramifications for quarantine targeting against closer contacts (Ooi et al. 2005). In other fields of health policy, research on quarantine continues to lack objective validity or consensus about how best to disclose discrepancies in results due to control measures (Bondy et al. 2009). Together with all such cases, the Ebola virus outbreak in West Africa that has long-term health consequences on patients, stringent public safety restrictions such as mandatory segregation and quarantine, suspensions of businesses and colleges and travel bans had a severe and permanent impact on the people and societies impacted (World Bank 2015). For example, the use of mass quarantine automatically limited the rights of citizens to equality and democracy and produced shortages of food and shelter and civil unrest. The provision of health care has deteriorated by $23 \%$ and other critical services such as water and sanitation have started to hinder (Valand et al. 2020). EVD survivors and their families also face prejudice in their communities; some survivors of being forced to relocate (Emrick et al. 2016).

\section{Economic impact of lockdown}

Death on such a broad scale due to COVID-19 has disrupted world commerce and supply chains lowered commodity rates and pressured multinationals to make tough choices with insufficient knowledge in China and globally. It is an important transport and commercial hub that houses the headquarters of the nation's main local steel and automobile manufacturers. The city now houses more than 300 factories of the top 500 firms in the country, including Microsoft, the German tech firm SAP and the French automaker Groupe PSA. In recent years, its monetary performance has surpassed the national growth, with gross domestic product (GDP) growth of $7.8 \%$ in 2019 relative to the national average of $6.1 \%$. Amid the outbreak of the latest viral disease, several businesses have now evacuated their expatriate employees from the city and immediately suspended their company activities temporarily (Mishra et al. 2020). The stringent travel restrictions placed in Wuhan and numerous urban areas in Hubei are likely to have ramifications in all of China and beyond, about trade. Among the industries that have been adversely impacted is the food, tourism and hospitality sectors (Mishra et al. 2020). The global economy was reported to have lost approximately $\$ 40$ billion during the SARS-CoV epidemic in China between 2002 and 2003. As China now has an economy of 8 to 9 times greater than it had before the SARS epidemic and is much more linked to the rest of the world. Analysts agree the total effect of the COVID-19 on the global economy will be very enormous. Despite China now contributing about $16.3 \%$ of the world's GDP, the country has become the world's leading growth force, with the IMF reporting that China alone accounted for $39 \%$ of global economic growth in 2019 (NBC news 2020). Taking into account the disruption of commerce, transport, tourism and significant impacts on global supply chains, the economic effects of the epidemic will be enormous both in China and globally. A business analysis by Bloomberg economists suggests that China's GDP growth in the first quarter will fall to 4.5 per cent year-on-year. Bloomberg economics conclude the full effect of the deadly disease is too early to say as the epidemic has not yet reached its height (Ayittey et al. 2020). COVID-19 situation has altered the lives in diverse public sectors including public, tourism, aviation, agriculture and economy (Nicola et al. 2020). COVID-19 pandemic has globally reduced the economy of different nations. During the 2014 and 2015 Ebola virus outbreak, the World Bank reported that Guinea, Liberia and Sierra 
Leone lost at least US\$ 2.2 billion in forgiven economic growth in 2015. Consumption development in rural Liberia has been stagnant between the HIES waves of 2014 and 2016. Rural poverty in the first half of 2014 (just before the Ebola crisis) rose from 70 percent to 82 percent in the first half of 2016 following the Ebola outbreak. Fear of meeting in communities has hindered the mobilization of workers and contributed to serious labour shortages, thus depriving rice production and, consequently rural welfare (Fuente et al. 2019).

The same refers to the 2003 SARS outbreak: the overall loss to the global economy of the SARS epidemic was estimated at least US\$ 40 billion (Lee and McKibbin 2004). The SARS outbreak created tremendous public concern and hysteria. At the height of the disease, public tourist arrivals plummeted significantly in those four countries that had the most SARS cases and resulting in an unprecedented $\$ 13$ billion loss of gross domestic product (GDP). However, these disruptions have not impacted any of these economies for longer than a few quarters and even countries most seriously affected have begun to rebound by Q3 2003 (Brahmbhatt and Arindam 2008). The economic effects of the SARS outbreak can be categorized into overt and indirect impacts. Specific effects included reduction of revenue and productivity due to mortality and symptomatic illness, as well as higher costs for health care. For this particular situation, indirect costs derive from collective behavioural shifts induced by the public's understanding of the outbreak (Noy and Shields 2003).

\section{Conclusion and prospects}

The infectious diseases caused by viruses and bacteria are fatal if they are not cured timely. These infectious diseases are contagious which means they spread the diseases from one infected person to another, consequently infect the entire community, nation and becomes a pandemic. In this review article, we have discussed almost all the viral and bacterial pandemics, their effects and preventive measures. Pandemics caused by any virus or any microorganism have affected the lives of the entire population of any country by disrupting the normal life cycle of people. Recently, the pandemic caused by COVID-19 has affected every sector of the globe including, education, transport, all types of businesses and the daily routine life of a man as well. Countries like the United States, European countries, the UK, Iran, India, China etc. are greatly affected by COVID-19. Worldwide, these viral pandemics have increased the mortality of the huge population. Moreover, other new issues for a nation have also risen including the declining economy of any country; increasing prices and unemployment are some of the serious issues of the COVID-19 pandemic. Presently, to prevent the infection caused by COVID-19, it is essential to avoid the public travelling to maintain the social distancing, other measures like lockdown and quarantine of the people are some of the strategies to control the viral infection. Though lockdown is the preventive measure of any viral pandemics, however, it has some ill consequences on the normal life of an individual such as obesity has more impact on diabetic and high blood pressure individuals, irritating behaviour, poor work efficiency of people and a wide gap in social relationship.

Therefore, to mitigate all the issues discussed above, it is essential to develop some effective diagnostic and therapeutic approaches that should be cost-effective, rapid, sensitive and specific. Recently, in the phase of COVID-19 pandemics, scientific communities across the globe are trying to synthesize the COVID-19 vaccine among them some are under human trial. Therefore, future research must be focused to design efficient vaccines and antiviral drugs against COVID-19. Till any vaccine has approved for human use, every country should aware of the people by educating, restrict public transport and providing some infection preventing devices such as the use of N-95 mask, sanitisers, use of $70 \%$ alcohol and any other authenticated disinfectant, avoiding surface contact, frequent hand and eye washing. Furthermore, the government of every country should design such strategies and policies which must be beneficial for every individual of a country.

Acknowledgements Dr. Neelam thankfully acknowledges the Dr. D.S. Kothari, University Grants Commission for the financial assistance.

Author contribution All the authors have contributed equally as detailed below.

Shariq Suleman and Asim Farooqui have written the draft manuscript. Pradakshina Sharma and Nitesh Malhotra have done a literature review and provided initial data. Neelam Yadav, Jagriti Narang, Md Saquib Hasnain and Amit Kumar Nayak supervised the work, rewrote the manuscript and overall corrections to reduce plagiarism and English corrections. All the authors thus provided scientific feedback on the review manuscript.

Data availability Not applicable.

\section{Declarations}

Ethics approval This is a review article so this work was not done on any living organism/animals.

Consent to participate Not applicable.

Consent for publication Not applicable.

Conflict of interest The authors declare no competing interests. 


\section{References}

Ahnert P, Creutz P, Horn K et al (2019) Sequential organ failure assessment score is an excellent operationalization of disease severity of adult patients with hospitalized community-acquired pneumonia - results from the prospective observational PROGRESS study. Crit Care 23:110

Aleya L, Gu W, Howard S (2021) Environmental factors and the epidemics of COVID-19

Al-Tawfiq JA, Memish ZA (2014) What are our pharmacotherapeutic options for MERS-CoV? Expert Rev Clin Pharmacol 7:235-238

Anderson RM, Fraser C, Ghani AC, Donnelly CA, Riley S, Ferguson NM, Leung GM, Lam TH, Hedley AJ (2004) Epidemiology, transmission dynamics and control of SARS: the 2002-2003 epidemic. Philosophical Transactions of the Royal Society of London. Series BBiolSci 359(1447):1091-1105

Assiri A, McGeer A, Perl TM, Price CS, Al Rabeeah AA, Cummings DA et al (2013) Hospital outbreak of Middle East respiratory syndrome coronavirus. N Engl J Med 369(5):407-416

Ayittey FK, Ayittey MK, Chiwero NB, Kamasah JS, Dzuvor C (2020) Economic impacts of Wuhan 2019-nCoV on China and the world. J Med Virol 2020:1-3

Ayres CF (2016) Identification of Zika virus vectors and implications for control. Lancet Infect Dis. 2016:278-279

Basarab M, Bowman C, Aarons EJ, Cropley I (2016) Zika Virus. BMJ 352:i1049

Bedford J, Enria D, Giesecke J, Heymann DL, Ihekweazu C, Kobinger G, Lane HC, Memish Z, Oh MD, Schuchat A, Ungchusak K (2020) COVID-19: towards controlling of a pandemic. Lancet

Bell DM, World Health Organization Writing Group (2006) Non-pharmaceutical interventions for pandemic influenza, international measures. Emerg Infect Dis 12:81-87

Bloom DE, Cadarette D (2019a) Infectious disease threats in the 21st century: strengthening the global response. Front Immunol 10:549

Bloom DE, Cadarette D (2019b) Infectious disease threats in the twenty-first century: strengthening the global response. Front Immunol 10:549

Bondy SJ, Russell ML, Laflèche JM, Rea E (2009) Quantifying the impact of community quarantine on SARS transmission in Ontario: estimation of secondary case count difference and number needed to quarantine. BMC Public Health 9(1):488

Bongomin F, Gago S, Oladele RO, Denning DW (2017) Global and multi-national prevalence of fungal diseases - estimate precision. J Fungi 3(4):57

Brahmbhatt M, Arindam D (2008) On SARS Type Economic Effects during Infectious Disease Outbreaks. World Bank, Washington, DC

Bramanti B, Stenseth NC, Walløe L, Lei X (2016) Plague: a disease which changed the path of human civilization. AdvExp Med Biol. 918:1-26

Bray M, Geisbert TW (2005) Ebola virus: the role of macrophages and dendritic cells in the pathogenesis of Ebola hemorrhagic fever. Int J Biochem Cell Biol 37(8):1560-1566

Bray M, Chertow DS, Hirsch MS, Mitty J (2015) Epidemiology and pathogenesis of Ebola virus disease. UpToDate, Waltham, MA (cited 2020 September 12)

Brooks SK, Dunn R, Amlôt R, Rubin GJ, Greenberg N (2018) A systematic, thematic review of social and occupational factors associated with psychological outcomes in healthcare employees during an infectious disease outbreak. J OccupatEnviron Med 60(3):248-257
Brower J, Chalk P (2003) The global threat of new and reemerging infectious diseases: reconciling US national security and public health policy (No. 1602). Rand Corporation

Centers for Disease Control and Prevention (2015) Interim US guidance for monitoring and movement of persons with potential Ebola virus exposure. Accessed 26 Oct 2015

Cetron M, Landwirth J (2005) Public health and ethical considerations in planning for quarantine. Yale J Biol Med 8:329-334

Chowell PW, Fenimore MA, Castillo-Garsow C (2003) Castillo-Chavez SARS outbreaks in Ontario, Hong Kong and Singapore: the role of diagnosis and isolation as a control mechanism. J TheorBiol 224:1-8

Cohen D (1974) The Black Death. Franklin Watts, New York, pp $1347-1351$

Cox NJ, Subbarao K (2000) Global epidemiology of influenza: past and present. Annu Rev Med 51:407-421

De La Fuente A, Jacoby HG, Lawin KG (2019) Impact of the West African Ebola epidemic on agricultural production and rural welfare: evidence from Liberia. The World Bank; 2019 Jun 11

Dennis DT et al (1999) Plague manual: epidemiology, distribution, surveillance and control. WHO, Geneva

Drancourt M, Houhamdi L, Raoult D (2006) Yersinia pestis as a telluric, human ectoparasite-borne organism. Lancet Infect Dis 6:234-241

El-Sayed A, Kamel M (2020) Climatic changes and their role in emergence and re-emergence of diseases. Environ Sci Pollut Res 27(18):22336-22352

El-Sayed A, Kamel M (2021) Coronaviruses in humans and animals: the role of bats in viral evolution. Environ Sci Pollut Res 1-12

El-Sayed A, Abdel-Daim MM, Kamel M (2021a) Causes of respiratory failure in COVID-19 patients. Environ Sci Pollut Res 1-6

El-Sayed A, Aleya L, Kamel M (2021b) COVID-19: a new emerging respiratory disease from the neurological perspective. Environ Sci Pollut Res 1-15

Emrick P, Gentry C, Morowit L (2016) Ebola virus disease: international perspective on enhanced health surveillance, disposition of the dead, and their effect on isolation and quarantine practices. DisastMilit Med 2(1):13

Estrada-García T, Mintz ED (1996) Cholera: foodborne transmission and its prevention. Eur J Epidemiol 12:461-469

Fenner FJ, McAuslan BR, Mims CA (2013) The biology of animal viruses. Elsevier. eISBN:9781483271880

Gage KL, Dennis DT, Tsai TF (1996) stacks.cdc.gov

Gani R, Leach S (2004) Epidemiologic determinants for modeling pneumonic plague outbreaks. Emerg Infect Dis 10:608-614

Goh K, Teo S, Lam S, Ling M (1990) Person-to-person transmission of cholera in a psychiatric hospital. J Infect 20:193

Gomes MFC, Pastore y Piontti A, Rossi L, Chao D, Longini I, Halloran ME et al (2014) Assessing the international spreading risk associated with the 2014 West African Ebola outbreak. PLoSCurr 1 pii= pii: ecurrents. outbreaks

Gostic K, Gomez AC, Mummah RO, Kucharski AJ, Lloyd-Smith JO (2020) Estimated effectiveness of symptom and risk screening to prevent the spread of COVID-19. Elife 9:e55570. https://doi. org/10.7554/eLife.55570

Grover S, Sahoo S, Mehra A, Avasthi A, Tripathi A, Subramanyan A, Pattojoshi A, Rao GP, Saha G, Mishra KK, Chakraborty K, Rao NP, Vaishnav M, Singh OP, Dalal PK, Chadda RK, Gupta R, Gautam S, Sarkar S, Sathyanarayana Rao TS, Kumar V, Janardran Reddy YC (2020) Psychological impact of COVID19 lockdown: an onlinesurvey from India. Indian J Psychiatry 62(4):354-362. https://doi.org/10.4103/psychiatry.IndianJPsy chiatry_427_20 
Halstead SB, Mahalingam S, Marovich MA, Ubol S, Mosser DM (2010) Intrinsic antibody-dependent enhancement of microbial infection in macrophages: disease regulation by immune complexes. The Lanc Infect Dis 10(10):712-722

He JF. (and 52 others) (2004) Molecular evolution of the SARS coronavirus during the course of the SARS epidemic in China. Sci 303:1666-1669. Health Affairs. Accessed February 8, 2020.

Hollmann A, Cardoso NP, Espeche JC, Maffía PC (2021) Review of antiviral peptides for use against zoonotic and selected nonzoonotic viruses. Peptides, 170570

Hossain MF, Hasana S, Al Mamun A, Uddin MS, Wahed MII, Sarker S et al (2020) COVID-19 outbreak: pathogenesis, current therapies, and potentials for future management. Front Pharmacol 11

Hossain MM, Tasnim S, Sultana A, Faizah F, Mazumder H, Zou L, McKyer ELJ, Ahmed HU, Ma P (2020) Epidemiology of mental health problems in COVID-19: a review. F1000Res 9:636. https://doi.org/10.12688/f1000research.24457.1

Huang C, Wang Y, Li X et al (2020) Clinical features of patients infected with 2019 novel coronavirus in Wuhan, China. Lancet 395:497-506

Interventions for Community Containment (n.d.) CDC 14 February 2020

Isaacs A, Gledhill AW, Andrewes CH (1952) Influenza A viruses; laboratory studies, with special reference to European outbreak of 1 . Bull World Health Org 6:287-315

Jacob ST, Crozier I, Fischer WA, Hewlett A, Kraft CS, de La Vega MA, Kuhn JH (2020) Ebola virus disease. Nature Rev Dis Primer 6(1):1-31

Jefferson T, Foxlee R, Del Mar C, Dooley L, Ferroni E, Hewak B, Prabhala A, Nair S, Rivetti A (2008) Physical interventions to interrupt or reduce the spread of respiratory viruses: systematic review. BMJ 336:77-80

Johnson NPAS, Mueller J (2002) Updating the accounts: global mortality of the 1918-1920 "Spanish" influenza epidemic. Bull Hist Med 76:105-115

Khan N, Fahad S, Faisal S, Akbar A, Naushad M (2020) Critical review of COVID-2019 in America and impacts on its economy. Available at: https://doi.org/10.2139/ssrn.3635062

Kugeler KJ, Staples JE, Hinckley AF, Gage KL, Mead PS (2015) Epidemiology of human plague in the United States, 1900-2012. Emerg Infect Dis 21:16-22

Lancet T (2020) India under COVID-19 lockdown. Lancet (London, England) 395(10233):1315

Lazear HM, Diamond MS (2016) Zika virus: new clinical syndromes and its emergence in the western hemisphere. JVirol 90:4864-4875

Lee JW, McKibbin W (2004) Estimating the global economic costs of SARS. In: Knobler S et al (eds) Learning from SARS: Preparing for the Next Disease Outbreak: Workshop Summary. National Academic Press, Washington, DC [Accessed 11 Jul 2017]

LePan N (2020) Visualizing the history of pandemics. Visual capitalist. com. Accessed October, 31

Madhav N, Oppenheim B, Gallivan M, Mulembakani P, Rubin E, Wolfe N. Pandemics: Risks, Impacts, and Mitigation. In: Jamison DT, Gelband H, Horton S, Jha P, Laxminarayan R, Mock CN, Nugent R, editors. Disease Control Priorities: Improving Health and Reducing Poverty. 3rd ed. Washington (DC): The InternationalBank for Reconstruction and Development / The World Bank; 2017 Nov 27. Chapter 17. PMID: "30212163

Malone R, Homan J, Callahan M, Glasspool-Malone J, Damodaran L, Schneider Ade B et al (2016) ZIKA: medical countermeasure development challenges. PLoSNegl. Trop Dis 10:e004530
Markel H (1997) QUARANTINE! East European Jewish Immigrants and the New York City Epidemics of 1892. The Johns Hopkins University Press, Baltimore

Maunder RG, Lancee WJ, Balderson KE, Bennett JP, Borgundvaag B, Evans S, Fernandes CM, Goldbloom DS, Gupta M, Hunter JJ, McGillis HL, Nagle LM, Peczeniuk SS, Raymond G, Read N, Rourke SB, Steinberg RJ, Stewart TE, VanDeVelde-Coke S, Veldhorst GG, Wasylenki DA (2006) Long-term psychological and occupational effects of providing hospital healthcare during SARS outbreak. Emerg Infect Dis 12(12):1924-1932

McLeod MA, Baker M, Wilson N, Kelly H, Kiedrzynski T, Kool JL (2008) Protective effect of maritime quarantine in South Pacific jurisdictions, 1918-19 influenza pandemic. Emerg Infect Dis $14: 468-470$

Meganck RM, Baric RS (2021) Developing therapeutic approaches for twenty-first-century emerging infectious viral diseases. Nat Med 27(3):401-410

Memish ZA, Cotten M, Watson SJ, Kellam P, Zumla A, Alhakeem RF et al (2014) Community case clusters of Middle East respiratory syndrome coronavirus in Hafr Al-Batin, Kingdom of Saudi Arabia: a descriptive genomic study. Int J Infect Dis 23:63-68

Memish ZA, Zumla A, Al-Hakeem RF, Al-Rabeeah AA, Stephens GM (2013) Family cluster of Middle East respiratory syndrome coronavirus infections. N Engl J Med 368(26):2487-2494

Mishra NP, Das SS, Yadav S, Khan W, Afzal M, Alarifi A, Nayak AK (2020) Global impacts of pre-and post-COVID-19 pandemic: focus on socio-economic consequences. SensInt 1:100042

Modesti PA, Wang J, Damasceno A, Agyemang C, Van Bortel L, Persu A, Schutte AE (2020) Indirect implicationsof COVID-19 prevention strategies on non-communicable diseases. BMC Med 18(1):1-16

Mehendale R, Joshi M, Patravale VB (2013) Nanomedicines for treatment of viral diseases. Critic Reviews ${ }^{\mathrm{TM}}$ Therapeut Drug Carrier Sys 30:1-49. https://doi.org/10.1615/CritRevTherDrugCarri erSyst.2013005469

NBC News (2020) . Accessed February 8, 2020

Nguyen-Van-Tam JS, Hampson AW (2003) The epidemiology and clinical impact of pandemic influenza. Vaccine 21:1762-1768

Nichol KL, Nordin JD, Nelson DB et al (2007) Effectiveness of influenza vaccine in the community-dwelling elderly. $\mathrm{N}$ Engl J Med 357:1373-1381

Nicola M, Alsafi Z, Sohrabi C, Kerwan A, Al-Jabir A, Iosifidis C, Agha M, Agha R (2020) The socioeconomic implications of the coronavirus pandemic (COVID-19): a review. Int J Surg 78:185-193. https://doi.org/10.1016/j.ijsu.2020.04.018

Nishiura H, Mizumoto K, Ejima K, Zhong Y, Cowling B, Omori R (2012) Incubation period as part of the case definition of severe respiratory illness caused by a novel coronavirus. Euro Surveill 17

Novavax D (2013) Novavax produces MERS CoV vaccine candidate. Accessed on 13 Apr 2017

Noy I, Shields S (2003) The 2003 severe acute respiratory syndrome epidemic: a retroactive examination of economic costs

Ooi PL, Lim S, Chew SK (2005) Use of quarantine in the control of SARS in Singapore. American J Infect Cont 33:252-257

Paital B, Das K, Parida SK (2020) Inter nation social lockdown versus medical care against COVID-19, amild environmental insight with special reference to India. Sci Total Environ 728:138914. https://doi.org/10.1016/j.scitotenv.2020.138914

Peak CM, Wesolowski A, ZuErbach-Schoenberg E, Tatem AJ, Wetter E, Lu X, Power D, Weidman-Grunewald E, Ramos S, Moritz S, Buckee CO (2018) Population mobility reductions associated with travel restrictions during the Ebola epidemic 
in Sierra Leone: use of mobile phone data. Int $\mathrm{J}$ Epidemiol 47(5):1562-1570

Plotkin JB, Dushoff J, Levin SA (2002) Hemagglutinin sequence clusters and the antigenic evolution of influenza A virus. ProcNat1AcadSci USA 99:6263-6268

Qureshi MO, Sajjad R (2018) World Health Organization's Disease Outbreak News, Advisory and Mitigation of Middle East Respiratory Syndrome. Med SafGlob Health 7:1-6

Randolph SE, Rogers DJ (2010) The arrival, establishment and spread of exotic diseases: patterns and predictions. Nature Rev Microbiol 8(5):361-371

Rather IA, Kumar S, Bajpai VK, Lim J, Park YH (2017) Prevention and control strategies to counterZika epidemic. Front Microbiol 8:305

Reusken CB, Raj VS, Koopmans MP, Haagmans BL (2016) Cross host transmission in the emergence of MERS coronavirus. CurrOpinVirol 16:55-62

Rothstein MA, Alcalde MG, Elster NR, Majumder MA, Palmer LI, Stone TH et al (2003) Quarantine and isolation: lessons learned from SARS, a report to the Centers for Disease Control and Prevention. Institute for Bioethics Health Policy and Law, University of Louisville School of Medicine, Louisville (KY), pp 1-160

Roy S (2020) COVID-19 pandemic: Impact of lockdown, contact and non-contact transmissions on infection dynamics. medRxiv

Sampathkumar P, Temesgen Z, Smith TF, Thompson RL (2003) SARS: Epidemiology, clinical presentation, management, and infection control measures. Mayo Clinic Proc 78(7):882-890

SARS (2005) Investigation Team from D.M.E.R.I. and S. G. H.: Strategies adopted and lessons learnt during the severe acute respiratory syndrome crisis in Singapore. Rev Med Virol 15:57-70

Serrano-Ripoll MJ, Meneses-Echavez JF, Ricci-Cabello I, Fraile-Navarro D, Fiol-deRoque MA, Pastor-Moreno G, Gonçalves-Bradley DC (2020) Impact of viral epidemic outbreaks on mental health of healthcare workers: a rapid systematic review and meta-analysis. J Affect Disord 277:347-357

Simonsen L, Clarke MJ, Williamson GD, Stroup DF, Arden NH, Schonberger LB (1997) The impact of influenza epidemics on mortality: introducing a severity index. Am J Public Health 87:1944-1950

Simonsen L, Reichert TA, Viboud C, Blackwelder WC, Taylor RJ, Miller MA (2005) Impact of influenza vaccination on seasonal mortality in the US elderly population. Arch Intern Med 165:265-272

Snijders D, Schoorl M, Schoorl M, Bartels PC, van der Werf TS, Boersma WG (2012) D-dimer levels in assessing severity and clinical outcome in patients with community-acquired pneumonia. A secondary analysis of a randomised clinical trial. Eur J Intern

Suwantarat N, Apisarnthanarak A (2015) Risks to healthcare workers with emerging diseases: lessons from MERS-CoV, Ebola, SARS, and avian flu. CurrOpin Infect Dis 28(4):349-361

Svoboda T, Henry B, Shulman L, Kennedy E, Rea E, Ng W, Wallington T, Yaffe B, Gournis E, Vicencio E et al (2004) Public health measures to control the spread of the severe acute respiratory syndrome during the outbreak in Toronto. The New Eng J Med 350:2352-2361

Tabish M, Khatoon A, Alkahtani S, Alkahtane A, Alghamdi J, Ahmed SA, Aljarba NH (2020) Approaches for prevention and environmental management of novel COVID-19. Environ Sci Pollut Res: $1-11$

Tian JP, Wang J (2011) Global stability for cholera epidemic models. Mathematical biosciences 232(1):31-41
Tognotti E (2003) Scientific triumphalism and learning from facts: bacteriology and the "Spanish flu" challenge of 1918. SocHist Med 16:97-110

Tognotti E (2013) Lessons from the history of quarantine, from plague to influenza A. Emerg Infectious Dis 19(2):254

Valand P, Miles J, Pandya AN (2020) The deleterious effects of war and conflict on the provision of health care for vulnerable populations and the potential effects of COVID-19 on vulnerable populations in conflictzones. IJS Glob Health 3:1-6

Viboud C, Tam T, Fleming D, Handel A, Miller MA, Simonsen L (2006) Transmissibility and mortality impact of epidemic and pandemic influenza, with emphasis on the unusually deadly 1951 epidemic. Vaccine 24(44-46):6701-6707

Wang D, Hu B, Hu C et al (2020) Clinical characteristics of 138 hospitalized patients with 2019 novel coronavirus-infected pneumonia in Wuhan, China. JAMA 2020; published online Feb 7. https:// doi.org/10.1001/jama.2020.1585

Watts J (2004) China culls wild animals to prevent new SARS threat. Lancet 363:134

WHO MERS-CoV Research Group (2013) State of knowledge and data gaps of Middle East respiratory syndrome coronavirus (MERS$\mathrm{CoV}$ ) in humans. PLoS Curr 5

WHO Report (2019)

WHO (2014) Ebola Response Team. Ebola virus disease in West Africa: the first 9 months of the epidemic and forward projections. N Engl J Med 371:1481-1495

WHO (n.d.-a) Global Alert and Response (GAR). Ebola situation report as of 18 March 2015. Accessed 24 March 2015

WHO (n.d.-b). Global Alert and Response (GAR). One year into the Ebola epidemic: a deadly, tenacious and unforgiving virus. http:// www.who.int/csr/disease/ebola/one-year-report/ebola-report-1year.pdf?ua $=1$. Accessed 8 Feb 2015. A recent summary and review of several aspects of Ebola from WHO

WHO (n.d.-c) Severe acute respiratory syndrome (SARS). http://www. who.int/csr/sars/en/. Accessed 24 Aug 2016

WHO (2016) WHO publishes list of top emerging diseases likely to cause major epidemics. WHO, Geneva. Available at: http://www. who.int/medicines/ebola-treatment/WHO-list-of-top-emergingdiseases/en/. Accessed 30 July 2016

Wong SS, Poon RW, Wong SC (2016) Zika virus infection- the next wave after dengue? J Formos Med Assoc 115:226-242. https:// doi.org/10.1016/j.jfma.2016.02.002

World Bank (2016) World Bank Group Ebola Response Fact Sheet, Available at, [Accessed $11 \mathrm{Jul}$ 2017]

World Bank (2015)Summary on the economic recovery plan: Sierra Leone. http://www.worldbank.org/en/topic/ebola/brief/summaryon-theebola-recovery-plan-sierra-leone. Accessed 26 Oct 2015

World Health Organization (2015) MERS-CoV in the Republic of Korea at a Glance. Accessed on April 17, 2019

World Health Organization web page (n.d.)

World Health Organization (2020) Modes of transmission of virus causing COVID-19: implications for IPC precaution recommendations: scientific brief, 29 March 2020 (No. WHO/2019-nCoV/ Sci_Brief/Transmission_modes/2020.2)

World Health Organization (2014) Interim surveillance recommendations for human infection with Middle East respiratory syndrome coronavirus. Accessed on April 10, 2017

Wu Z, McGoogan JM (2020) Characteristics of and important lessons from the coronavirus disease 2019 (COVID-19) outbreak in China: summary of a report of 72314 cases from the Chinese Center for Disease Control and Prevention. JAMA; published online Feb 24 
Xiong J, Lipsitz O, Nasri F, Lui LMW, Gill H, Phan L, Chen-Li D, Iacobucci M, Ho R, Majeed A, McIntyre RS (2020) Impact of COVID-19 pandemic on mental health in the general population: a systematic review. J Affect Disord 277:55-64. https://doi.org/ 10.1016/j.jad.2020.08.001

Zaki AM, van Boheemen S, Bestebroer TM, Osterhaus AD, Fouchier RA (2012) Isolation of a novel coronavirus from a man with pneumonia in Saudi Arabia. N Engl J Med 367:1814-1820

Zhou F, Yu T, Du R et al (2020) Clinical course and risk factors for mortality of adult inpatients with COVID-19 in Wuhan, China: a retrospective cohort study. Lancet. Published online March 9
Zumla A, Alagaili AN, Cotten M, Azhar EI (2016) Infectious diseases epidemic threats and mass gatherings: refocusing global attention on the continuing spread of the Middle East Respiratory syndrome coronavirus (MERS-CoV). BMC med 14(1):132

Zumla A, Hui DS, Perlman S (2015) Middle East respiratory syndrome. Lancet 386:995-1007

Publisher's note Springer Nature remains neutral with regard to jurisdictional claims in published maps and institutional affiliations. 